\title{
EFFECT OF BENZOTHIAZOLE COMPLEXES ON PHOTODEGRDATION RATE CONSTANTS OF POLYVINYL CHLORIDE FILMS
}

\author{
Emad Yousif ${ }^{1}$, Hadeel Adel ${ }^{1}$, Raghad Haddad ${ }^{1}$, and Rahimi Yusop ${ }^{2}$ \\ 1 Department of Chemistry, College of Science, Al-Nahrain University, Baghdad, Iraq \\ 2 School of Chemical Sciences \& Food Technology, Faculty of Science and Technology, Universiti Kebangsaan, Malaysia \\ Email: emad_yousif@hotmail.com
}

\begin{abstract}
Five coordination complexes of $\mathrm{Ni}(\mathrm{II}), \mathrm{Cu}(\mathrm{II}), \mathrm{Zn}(\mathrm{II}), \mathrm{Cd}(\mathrm{II})$ and $\mathrm{Sn}$ (II) metal with [2-thioacetic acid benzothiazole] were prepared in an alcoholic medium and used as photostabilizer for polyvinyl chloride against degradation. PVC was mixed with these complexes in a THF solvent to form a modified PVC in $(5 \%) \mathrm{w} / \mathrm{v}$ thickness, which containing $0.5 \%$ by weight concentration of complex were produced by casting method from solvent. The light of the wavelength $365 \mathrm{~nm}$ with intensity $(6.0254 \mathrm{X}$ $10^{-9} \mathrm{E}$ in $\mathrm{Dm}^{-3} \mathrm{~S}^{-1}$ ) was used for irradiation of PVC films at room temperature. The photostabilization of PVC films compounds was investigated and the photostabilization action of these compounds was determined by calculating the photodecomposition rate constant $\left(K_{d}\right)$ for blank and modified PVC films.
\end{abstract}

Keywords: Polyvinyl chloride, Photodegradation, Benzothiazole, Photostabilization, UV Visible spectroscopy.

\section{INTRODUCTION}

Benzothiazole is an aromatic heterocyclic compounds with the chemical formula $\mathrm{C}_{7} \mathrm{H}_{5} \mathrm{NS}$. It consists of a 5 membered 1,3thiazole ring fused to benzene ring. The aromatic benzothiazole nucleus is associated with a variety of antihistamine activity, pharmacological actions such as fungicide [1-3]. These activities are probably due to the presence of the $-\mathrm{N}=\mathrm{C}-\mathrm{S}$ group. Substituted benzothiazole have been accounted to show different applications as photostablizer and metal complexing [4-6]. Poly (vinyl chloride) PVC is a thermoplastic polymer and is the third largest produced polymer in the world [7]. It is one of the most important technical polymers that has wide applicability $[8,9]$. Utilization of PVC in building, mainly in outdoor applications such as window profiles and cladding structure [10] is due to the low cost and the good performance of this polymer compared with others. In recent years, the utilization of polymeric materials has expanded. Nonetheless, it is well established that rapid photodegradation of these materials is possible when they are exposed to natural weathering [10-12]. A wide variety of manufactured and natural polymers absorb solar ultraviolet radiation and undergo photolytic, photo oxidative, and thermo oxidative reactions due to the degradation of the materials [13-15]. Solar radiation reaching to the surface of the earth is characterized by wave lengths from approximately 295 up to $2500 \mathrm{~nm}$. Solar radiation can be classified into: UV-B (280 $315 \mathrm{~nm}$ ), UV-A (315 - $400 \mathrm{~nm}$ ), Visible (400 
- $760 \mathrm{~nm})$, and infrared (760 - 2500nm.). UV-B has an energy of $426-380 \mathrm{~kJ} \mathrm{~mol}^{-1}$. Fortunately, the higher energetic part of UVB; 280 - $295 \mathrm{~nm}$, is filtered by the stratosphere and does not reach the earth's surface, but UV-A has energy between 389 and $300 \mathrm{~kJ} \mathrm{~mol}^{-1}$ and is less harmful for organic materials than UV-B. [16]. To ensure the weather ability of these materials, the PVC needs to be mixed and processed properly using suitable additives, leading to complex materials whose behavior and properties are truly unique in relation to virgin PVC (PVC blank) [17]. All manufactured polymers require stabilizers against the adverse effects; it becomes necessary to find ways to prevent, or to reduce, the damage caused by the environmental parameters such as light, air and heat. The photostabilization of polymers means the retardation or elimination of photochemical process in polymers and plastics that occur during irradiation $[18-22]$. As part of our programs on photo stabilization, the photo stabilization of PVC was studied by using 2thioacetic acid benzothiazole complexes and using the UV-spectra for measuring the photo decomposition rate constant $\left(\mathrm{K}_{\mathrm{d}}\right)$ values for each films.

\section{EXPERIMENTAL MATERIALS}

All of the reagents and starting materials used in the present work are of reagent grade and were used without further purifications unless otherwise noted. The complexes below were prepared by the method reported before [23]:

These complexes are:

1. Bis(2-thioacetic acid benzothiazole) Nickel(II), $\mathrm{Ni}(\mathrm{L})_{2}$.

2. Bis(2-thioacetic acid benzothiazole) Cupper(II), $\mathrm{Cu}(\mathrm{L})_{2}$.

3. $\operatorname{Bis}\left(2-\right.$ thioacetic acid benzothiazole) $\mathrm{Zinc}(\mathrm{II}), \mathrm{Zn}(\mathrm{L})_{2}$.

4. Bis(2-thioacetic acid benzothiazole) Cadmium(II), $\mathrm{Cd}(\mathrm{L})_{2}$.

5. Bis(2-thioacetic acid benzothiazole) Tin(II), $S n(L)_{2}$.
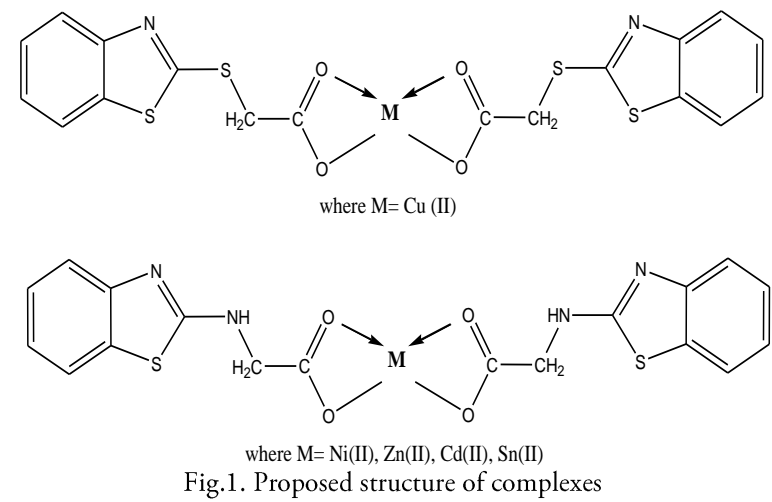

The structure of complexes is shown in Figure 1.

\section{EXPERIMENTAL TECHNIQUES FILMS PREPARATION}

A solution of polyvinyl chloride $(5 \% \mathrm{w} / \mathrm{v})$ in THF was used to prepare $(30 \mu \mathrm{m})$ thickness of polymer films. The PVC used in this work has $96 \%$ purity and was supplied from BHD and THF has $99 \%$ purity and was supplied from Hopkin and Williams Company. The films were prepared by evaporation technique at room temperature for 24 hours, to remove the conceivable remaining solvent. The evaporation of the solvent led to the formation of PVC films. However modified PVC can be prepared using the same method above by mixing of $0.5 \%$ by weight complexes to the solution containing polyvinyl chloride [24].

\section{IRRADIATION EXPERIMENTS}

\section{ACCelerated Testing TeChNique}

UV Light was used for the irradiation of PVC films, giving wavelength ranges between (250 to $380 \mathrm{~nm}$ ). The maximum wavelength light

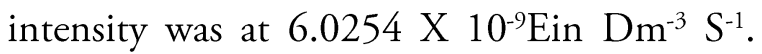
The polymer film samples were settled parallel to one another and the lamp of the UV incident radiation was vertically incident on the samples. The distance between the polymer films and the source of light was $(10 \mathrm{~cm})$ [25]. The films are irradiated for 250 hours at room temperature. 


\section{PHOTODEGRADATION MEASURING METHODS}

MEASURING THE PHOTODEgRADATION RATE OF PVC FILMS BY USING ULTRAVIOLET-VISIBLE SPECTROPHOTOMETER

An ultraviolet-visible spectrophotometer type Shimadzu UV-VIS 160 was used to measure the changes in the UV - visible spectrum during irradiation time for each compound at maximum absorption band $\left(\lambda_{\max }\right)$. The absorption spectrum was measured in the range of $(200-400 \mathrm{~nm})$, and the $\left(\lambda_{\max }\right)$ at each absorption was also recorded for different irradiation times.

The infinite irradiation time was considered and the infinite absorption $\left(A_{\infty}\right)$ was assumed to be after the infinite irradiation time.

To determine the photodegradation rate constant for photostabilizer $\left(K_{d}\right)$, the first order equation was used:

$\ln (\mathrm{a}-\mathrm{x})=\ln \mathrm{a}-\mathrm{K}_{\mathrm{d}} \mathrm{t}$

where a represents the stabilizer concentration before irradiation and $x$ the change in stabilizer concentration after irradiation time (t).

If $A_{o}$ represents the absorption intensity of the polymer film containing stabilizer before irradiation, $A_{t}$ represents the absorption intensity after $t$ time of irradiation, then:

$\mathrm{a}=\mathrm{A}_{0}-\mathrm{A}_{\infty}$

$\mathrm{x}=\mathrm{A}_{\mathrm{o}}-\mathrm{A}_{\mathrm{t}}$

$a-x=A_{o}-A_{\infty}-A_{o}+A_{t}=A_{t}-A_{\infty}$

Substitution of $\mathrm{a}$ and $(\mathrm{a}-\mathrm{x})$ from equation (2) in (1) gives:

$\ln \left(\mathrm{A}_{\mathrm{t}}-\mathrm{A}_{\infty}\right)=\ln \left(\mathrm{A}_{0}-\mathrm{A}_{\infty}\right)-\mathrm{K}_{\mathrm{d}} \mathrm{t}$

Thus a plot of $\ln \left(A_{t}-A_{\infty}\right)$ versus irradiation time $(t)$ gives straight line with a slope equal $\left(\mathrm{K}_{\mathrm{d}}\right)$ which indicates that photodecomposition of the additives is first order [26].

\section{RESULTS AND DISCUSSION}

\subsection{EFFICIENCY OF PREPARED COMPLEXES AS PHOTOSTABILIZERS}

Ultraviolet radiations have harmful effects on most industrial polymers inducing chemical modification and scission of polymer chain, which ultimately leads to the loss of the mechanical and surface properties of the irradiated material. Photodegradation of PVC causes discoloration (yellowing), cross-linking, and chain scission because of oxidation and the effect of UV light and heat [27-28]. UV light induces the production of radicals by oxidation. It is generally accepted that photodegradation and photothermal degradation occur with the discoloration of the polymer due to the polyene formation. Furthermore, carbonyl and polyene groups, formed during UV irradiation of PVC, is most probable and are responsible for the yellow coloration of the polymer [29-31]. The prepared complexes were used as photostabilizers to PVC films comparing with PVC blanks. The additives used in this study were chosen to be completely soluble in polymer solvent, (THF). It was noticed that the additives used in the present work are photodecomposed during the photolysis [32-33]. Thus, the photo decomposition rate constant $\left(K_{d}\right)$ was calculated. The $K_{d}$ values were computed using the UV spectra changes of PVC films thickness $30 \mu \mathrm{m}$ containing $0.5 \% \mathrm{w} / \mathrm{w}$ from additives. The plot of irradiation time versus $\ln \left(\mathrm{A}_{\mathrm{t}}-\mathrm{A}_{\infty}\right)$, gives straight line which indicates primarily the first order reaction. The slope equal to the decomposition rate constant $K_{d}$. Figure 2 shows the variation of $\ln \left(A_{t}-A_{\infty}\right)$ with irradiation time for all additives in PVC films at $\lambda=365 \mathrm{~nm}$. 


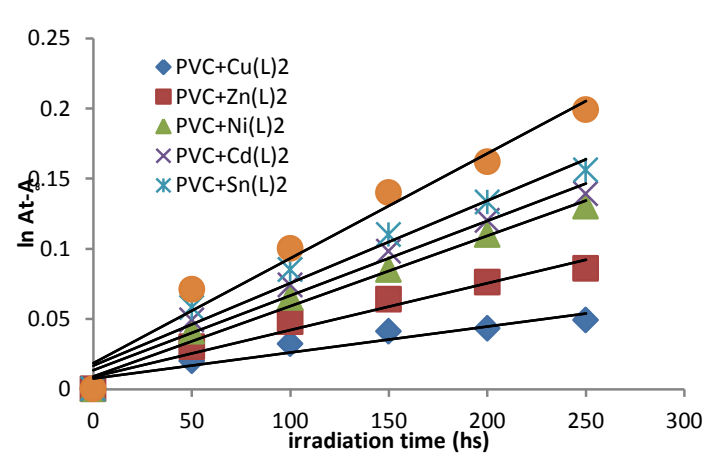

Fig.2. Variation of natural logarithm of $\ln \left(A_{t}-A_{\infty}\right)$ with irradiation time of additives in PVC films

The values of the first order rate constant of all the modified polymers films $\left(K_{d}\right)$ were calculated by the same way as in Table 1 .

The photostabilizers always possess low $K_{d}$ values, which mean that these modified polymers are stable towards UV light. One could notice that $K_{d}$ values are sensitive to the type of additives in PVC films, which decrease in the order below and this might point out to an increase in the photostability of these additives in this term: $\mathrm{Cu}(\mathrm{L})_{2}>\mathrm{Zn}(\mathrm{L})_{2}>$ $\mathrm{Ni}(\mathrm{L})_{2}>\mathrm{Cd}(\mathrm{L})_{2}>\mathrm{Sn}(\mathrm{L})_{2}$.

\subsection{SUGGESTED MECHANISMS OF PHOTOSTABILIZATION OF PVC BY THE2- THIOACETIC ACID BENZOTHIAZOLE COMPLEXES}

Through the overall results obtained, the efficiency of 2-thioacetic acid benzothiazole complexes as stabilizers for PVC films can be arranged according to the $\mathrm{K}_{\mathrm{d}}$ values $\mathrm{Cu}(\mathrm{L})_{2}>$ $\mathrm{Zn}(\mathrm{L})_{2}>\mathrm{Ni}(\mathrm{L})_{2}>\mathrm{Cd}(\mathrm{L})_{2}>\mathrm{Sn}(\mathrm{L})_{2}$ Metal carboxylates stabilize PVC by mechanisms, depending on the metal.

TABlE 1: PHOTODECOMPOSITION RATE CONSTANT $\left(\mathrm{K}_{\mathrm{D}}\right)$ OF PVC FILMS THICKNESS $(30 \mu \mathrm{m})$ CONTAINING $0.5 \%$ OF ADDITIVES

\begin{tabular}{|c|c|}
\hline Polymers & $\mathrm{K}_{\mathbf{d}} \mathbf{X} \mathbf{1 0}^{-4}\left(\mathbf{S}^{-1}\right)$ \\
\hline PVC (blank) & 7.474 \\
\hline PVC $+\mathrm{Sn}(\mathrm{L})_{2}$ & 5.886 \\
\hline $\mathrm{PVC}+\mathrm{Cd}(\mathrm{L})_{2}$ & 5.326 \\
\hline $\mathrm{PVC}+\mathrm{Ni}(\mathrm{L})_{2}$ & 5.011 \\
\hline $\mathrm{PVC}+\mathrm{Zn}(\mathrm{L})_{2}$ & 3.337 \\
\hline $\mathrm{PVC}+\mathrm{Cu}(\mathrm{L})_{2}$ & 1.846 \\
\hline
\end{tabular}

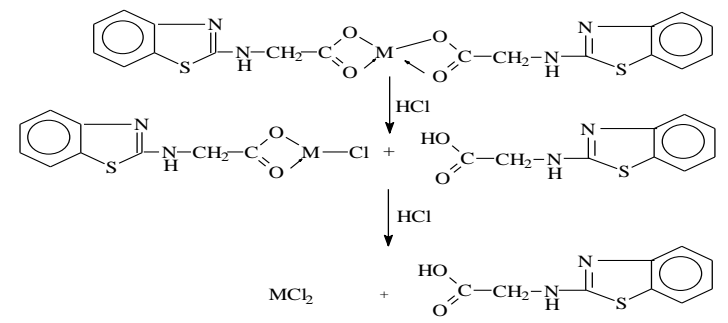

Scheme 3 Suggested mechanism of photostabilization of $S \mathrm{n}(\mathrm{L})_{2}$, $\mathrm{Zn}(\mathrm{L})_{2}, \mathrm{Cd}(\mathrm{L})_{2}, \mathrm{Ni}(\mathrm{L})_{2}$ and $\mathrm{Cu}(\mathrm{L})_{2}$ complexes as $\mathrm{HCl}$ scavengers.

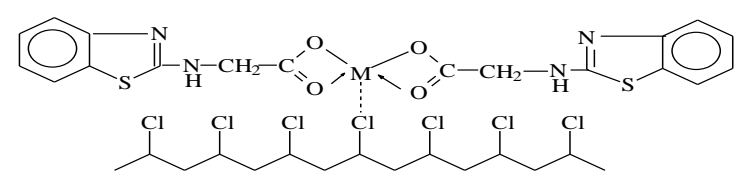

Scheme 4 Suggested mechanism of photostabilization of $\mathrm{Sn}(\mathrm{H})_{2}$ $\mathrm{Zn}(\mathrm{H})_{2}, \mathrm{Cd}(\mathrm{H})_{2}, \mathrm{Ni}(\mathrm{H})_{2}$ and $\mathrm{Cu}(\mathrm{H})_{2}$ complexes as primary stabilizers

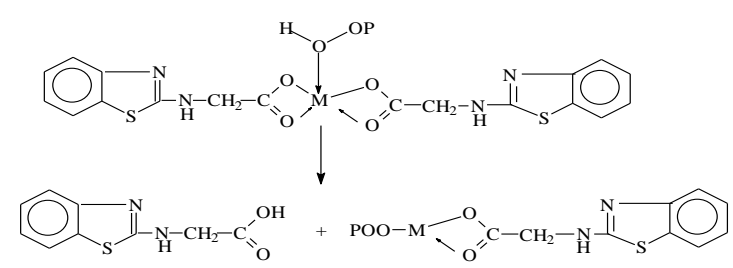

Scheme 5 Suggested mechanism of photostabilization of $\mathrm{M}(\mathrm{H})_{2}$ complexes as peroxide decomposer

Metals such as $\mathrm{Sn}, \mathrm{Cd} \mathrm{Zn,} \mathrm{Ni} \mathrm{and} \mathrm{Cu}$ which are stronger than Lewis acids and form covalent carboxylates, not only scavenge $\mathrm{HCl}$, but also substitute carboxylate for the allylic chlorine atoms. These stabilizers provide very good long-term stabilityandare usually referred to as secondary stabilizers (Scheme 3). IR spectroscopy has shown that metals carboxylates [34] associate with PVC molecules at the surface of primary particles and are, consequently, very effective in the substitution of allylic chlorine. In this mechanism the stabilizer is classified as primary stabilizers (scheme 4).

It has been postulated that metal stabilizers associate with chlorine atoms at the surface of PVC primary particles, which explains their high efficiency in PVC stabilization (Scheme 5). Therefore, it is expected that these complexes act as peroxide decomposer through the following proposed mechanism (Scheme 5). 

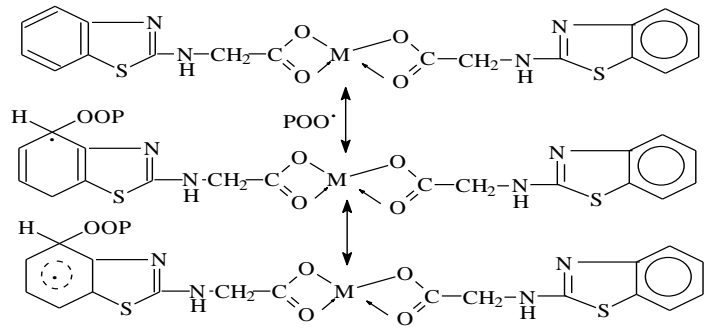

Scheme 6 Suggested mechanism of photostabilization of carboxylates complexes as radical scavengers

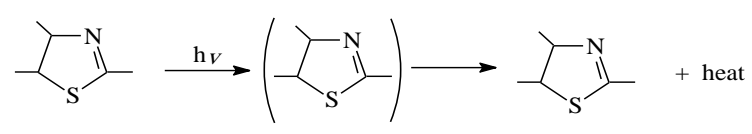

Scheme 7 Suggested mechanism of photostabilization of benzothiazole as UVabsorber

These metal chelate complexes also function as radical scavengers through energy transfer [35] and by forming unreactivecharge, transfer complexes between the metal chelate and excited state of the chromophore (POO.) and stabilize through resonating structures as shown in (Scheme 6).

The benzothiazole rings in these modified polymers plays a role in the mechanism of the stabilizer process by acting as a UV absorber [36] by dissipating the UV energy to harmless heat energy (Scheme 7).

\section{CONCLUSION}

The addition of $\mathrm{Ni}(\mathrm{II}), \mathrm{Cu}(\mathrm{II}), \mathrm{Zn}(\mathrm{II}), \mathrm{Cd}(\mathrm{II})$ complex and Sn (II) metal with [2-thioacetic acid benzothiazole] to polyvinyl chloride (PVC) films in $0.5 \%$ by weight concentrations have successfully worked as photostabilizers the degradation process for PVC films. The photostabilizers always possess low $\left(K_{d}\right)$ values, which mean that these modified polymers are stable towards UV light. Through the overall results obtained, the efficiency of complexes as stabilizers for PVC films against degradation can be arranged according to the $\mathrm{K}_{\mathrm{d}}$ values $\mathrm{Cu}(\mathrm{L})_{2}>\mathrm{Zn}(\mathrm{L})_{2}>\mathrm{Ni}(\mathrm{L})_{2}>\mathrm{Cd}(\mathrm{L})_{2}>\mathrm{Sn}(\mathrm{L})_{2}$.

\section{ACKNOWLEDGEMENTS}

We gratefully acknowledge the funding support from the staff of the chemistry department in College of Science- Al-Nahrain University- Baghdad - Iraq, and Universiti Kebangsaan Malaysia for the funding (Codes AP-2011 17, DPP-2013-054, UKM-MIOUP-2011, AP-2012-017, and DLP 2013002).

\section{REFERENCES}

[1] E. Brzezin, G. Kos'kaa, and K. Walczyn'skib, "Application of thin-layer chromatographic data in quantitative structure-activity relationship assay of thiazole and benzothiazole derivatives with $\mathrm{H}$-antihistamine activity". J. Chrom., 1007, 2003, pp. 145-155.

[2] A. Rana, N. Siddiqui, S. Khan, S. Haque and M. Bhat, "N-\{[(6-Substituted-1,3- benzothiazole-2-yl) amino]carbonothioyl\}-2/4- substituted benzamides: Synthesis and pharmacological evaluation”, Eur. J. Med. Chem., 43, 2008, pp. 1114-1122.

[3] W. Huang, and G. Yang, "Microwave assisted, one pot syntheses and fungicidal activity of polyfluorinated 2-benzylthiobenzothiazoles“, Bio. Med. Chem., 14, 2006, pp. 8280-8285.

[4] F. Tellez, V. Pena-Hueso, N. Barba-Behrens, R. Contreras, and A. Flores-Parra, "Coordination compounds in a pentacyclic aromatic system from 2-aminobenzothiazole derivatives and transition metal ions. Polyled.", 25, 2006, pp. 2363-2374.

[5] S. Pinheiro, J. de Sousa, M. Santiago, I. Carvalho, A. Silva, A. Batista, E. Castellano, V. Ram, U. Singhab and P. Gurub, "Chemotherapeutic agents XI: Synthesis of pyrimidines and azolopyrimidines as leishmanicides". Eur. J. Med. Chem., 25, 1990, pp. 533-538.

[6] E. Yousif, Y. Farina, K. Kasar, A. Graisa and Ayid K., "Complexes of 2-Thioacetic Acid Benzothiazole with Some Metal Ions", American J. of Appl. Sci. 6 (4), 2009, pp. 582-585.

[7] M. Kutz, "Applied Plastic Engeering Handbook", Elsevier, 2011.

[8] E. Yousif, R.Yusop, A. Ahmed, J. Salimon, and Salih N., "Photostabilization efficiency of PVC 
Based epoxidizedoilic acid", Malaysian J. of Analytical Sci., 19 (1), 2015, pp. 213-221.

[9] M. Sabaa, E. Oraby, A. Abdul Naby, and R. Mohamed, "N-phenyl-3-substituted 5-Pyrazolone derivatives as organic stabilizer for rigid PVC against photodegradation”, J. of Appl.Polym.Sci., 101, 2005, pp. 1543-1555.

[10] J. Pospisil, J. Pilar, C. Billingham, A. Marek, Z. Horak, and S. Nespurek, "Factors affecting accelerated testing of polymer photostability, Polymer Degradation Stabilization”, 91, 2006, pp. 417-422.

[11] J. Koleske, and L. Wartman, "Poly(Vinyl Chloride)", Ass. Macdonald Technical \& Scientific, London, 1969.

[12] B. Ivan, J. P. Kenedy, T. Kelen, and F. Toudos, T. T. Nagy, B. Torscanyi, "Degradation of PVC Obtained by Controlled Chemical Dehydrochlorination", Journal of Polymer Science. 21, 1983, pp. 2177-88.

[13] G. Scott, "Green polymers, Polymer Degradation and Stabilization”, 68, 2000, pp. 1-7.

[14] L. Valkoa, E. Kleinb, P. Kovarikb, and P. Simonb, "Ultra-violet spectra studies of photodegradation of PVC films in presence of Fe (III) chelate complex", Eur. Polym. J. , 37, 2001, pp. 1123-1133.

[15] N. Grassie, and G. Scott, "Polymer Degradation and Stabilization", Cambridge University Press, London, 1985.

[16] F. Rabek, "Polymer photodegradation of polymers: physical characteristic and applications", Springer- verlag, Beelin, 1996.

[17] A. Galdi, P. Foltis, and A. Shah, "UV protecting composition and methods of use", US patent, Application, 2010, pp. 2010-118415.

[18] E. Yousif, J. Salimon, and N. Salih, "New stabilizer for polystyrene based on 2-Thioacetic Acid Benzothiazol complexes", J. of applied polymer Science, 125, 2012, pp. 1922-1927.

[19] E.Yousif, J.Salimon, and N.Salih, "New stabilizer for polystyrene based on 2-N-Salicylidene-5(substituted)-1,3,4-thiadiazole compoundes", J. of Saudia Chem.Soci., 16, 2011, pp. 299-306.

[20] E. Yousif and R. Haddad, "Photodegradation and photostabilization of polymers, especially polystyrene: Review”, Springer Plus, 2, 2013, pp. 398-460.
[21] E. Yousif, R. Haddad, and A. Ahmed, "Photodegradation and photostabilization of polymers, especially polystyrene”, Lambert Academic Publishing, Germany, 2013.

[22] J. Rabek, and B. Ranby, "Studies on the photooxidation mechanism of polymers. II. The role of quinones as sensitizers in the photooxidative degradation of polystyrene", J. of Polym. Sci., 2(2), 2003, pp. 295-306.

[23] E. Yousif, H. Adil and Y. Farina, "Synthesis and Characterization of Some Metal Ions with 2amino Acetate Benzothiazole",J. of Appl. Sci. Research, 6(7), 2010, pp. 879-882.

[24] E. Yousif, A. Hameed, N. Salih, J. Salimon, and BM.Abdullah, "New photostabilizers for polystyrene based on 2,3-dihydro-(5-mercapto1,3,4-oxadiazol-2-yl)-phenyl-2-(substituted)-

1,3,4-oxazepine- 4,7-dione compounds", Springer Plus J., 2013, pp. 1-8.

[25] E. Yousif, J. Salimon, and N. Salih, "Improvement of photostabilization of PVC in the presence of thioaciticacidbenzothiazole complexes", The Malaysian J. of Anal. Sci., 15(1), 2011, pp. 81-92.

[26] E.Yousif, "Photostabilization of PVC by 1,3,4thiadiazole and 1,3,4, oxadiazole chelate complexes and some of their free ligand", $\mathrm{Ph} \mathrm{D}$ thesis, Al- Nahraine university, 2004.

[27] F. Rabek, "Mechanism of Photophysical Process and Photochemical Reaction in polymers", John Wiley and Sons, New York, 1987.

[28] S. Kiatkamjornwong, M. Sonsuk, S. Wittayapichet, P. Prasassarakich, and P. Vejjanukroh, "Degradation of styrene-g-cassava starch filled polystyrene plastics”, Polym. Degrad. Stab., 66, 1999, pp. 323-334.

[29] W. Gibb and J. Mac Callum, "The photodegradation of poly(vinyl chloride) filmsII "European Polymer Journal 8, 11, 1972, pp. 1223-1230.

[30] F. Mori, M. Koyama and Y. Oki, "Studies on photodegradation of poly(vinyl chloride)", part 3, Angew. Makromol. Chem., 75, 1979, pp. 113122.

[31] F. Gugumus, "Development in Polymers Stabilization”, Applied Science Publishers Ltd., London, 1979, pp. 261.

[32] E. Yousif, R. Haddad, A. Ameer, and Y. Win, "Ultra-violet spectra studies of photodegradation of PVC films in presence of $\mathrm{Fe}$ (III) chelate 
complex", European J. of Chem. 5 (4), 2014, pp. 607-611.

[33] E. Yousif, and A. Hasan, "Ultra-violet spectra studies of photostabilization rate in PVC films by using some transition metal complexes", Arab J. of Phys. Chem., 1(2), 2014, pp. 32-38.

[34] E. Yousif, J. Salimon, and N. Salih, "New photostabilizers for PVC based on some diorganotin(IV) complexes", Journal of Saudi Chemical Society, 19, 2015, pp. 133-141.

[35] B. Willis, "Investigation of test method material properties and processes for solar cell in capsulation", Eighth annual report, NASA-CR169636, United States 1984, pp. 1-145.

[36] A. Balakit, A. Ahmed, G. El-Hiti, K. Smith, and E. Yousif, "Synthesis of New Thiophene Derivatives and Their Use as Photostabilizers for Rigid Poly(vinyl chloride)", International J. of Polym. Sci., 2015, 2015, pp. 1-10. 


\title{
دراسة ثابت تفكك افلام متعدد كلوريد الفنيل بوجود معقد البنزوثايزول
}

\author{
عماد يوسف1، هديل عادل1، رغد حداد1، رحيمي بعسوب2

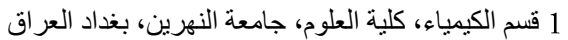

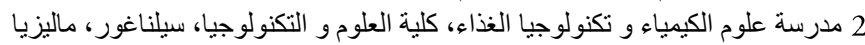

الملخص:

تم تحضير المعقدات المكونة من الليكند مع كل من النيكل (II))، النحاس (II)، الخارصين (II)، الكادميوم (II) و القصدير(II). وقد تم استخدام هذه المركبات (المعقدات) كمثبتات ضوئية لرقائق متعدد كلوريد الفنيل . أجريت عمليات التثبيت الضوئي كلوريد الفنيل من خلال مزج المعقدات المضرة مع البوليمر بوجود مذيب THF وبوزن 0.05 غر ام، وسمك البوليمر 30 مايكرمنر ، وبعدها تم تحضير رقائق من كل من (البوليمر مع المضافات) و (البوليمر بدون إضافات). وقد استخدم في تشعيع الرقائق البوليمرية ضوء بطول موجي 365 نانومتر.

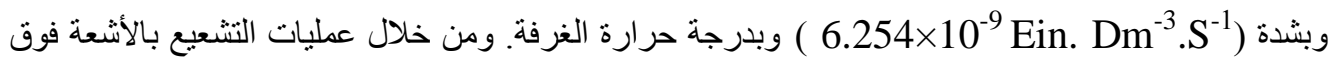
البنفسجية لهذه الرقائق حيث ان سرعــــة التكســـر الضـــــئي لرقائق متعدد كلوريد الفنيل خلال ساعات التشعيع يمكن منابعتها من خلال حساب ثنابت التكسر الضوئي للبوليمر بوجود و عدم وجود المعقدات. 